\title{
Evaluation of a short-term ingestion of zearalenone, fumonisin, and aflatoxin mixture incorporated, at low concentration, into the diet of weanling piglets and the effect of an anti-mycotoxin feed additive
}

\author{
Avaliação tóxica de uma dieta multicontaminada com baixa \\ concentração de zearalenona, fumonisina e aflatoxina em leitões \\ recém desmamados e o efeito de um aditivo antimicotoxinas
}

\author{
Antonio Diego Brandão Melo ${ }^{1 *}$; Angela Oliveira ${ }^{2}$; Geovane Rosa de Oliveira ${ }^{1}$; \\ Chiara Domingues ${ }^{1}$; Kelly Mazutti ${ }^{3}$; Jair Engracia Filho ${ }^{3}$; Pedro Celso Machado \\ Júnior"; Carla de Andrade ${ }^{5}$; Leandro Batista Costa ${ }^{3}$
}

\begin{abstract}
An experiment was conducted to evaluate the toxic effects of short-term ingestion of a zearalenone, fumonisin, and aflatoxin mixture, at low concentration, into the diet of weanling piglets and to assess the protective efficacy of an anti-mycotoxin feed additive. For 21 days, piglets were exposed to control or multi-mycotoxin treatment with or without the anti-mycotoxin additive. Growth performance was measured after $21 \mathrm{~d}$. Blood samples were taken to serum biochemical analysis and for quantify levels of circulating mononuclear immune cells. Effects on organs weights and histological changes, and expression levels of COX-2 and TNF- $\alpha$ in the liver and jejunum were evaluated. Overall, the multimycotoxin treatment had no effect on measured variables, and no adverse histopathological changes in organs were observed. The total serum protein concentration was higher in animals that received the multi-mycotoxin treatment; however, levels remained within normal limits for weanling piglets. In conclusion, the short-term multi-mycotoxin mixture, at the dose levels evaluated in this study, seems not affect the health of weanling piglets through the evaluated parameters. The absence of toxicity associated with the multi-mycotoxin treatment rendered it impossible to evaluate the efficacy of the anti-mycotoxin additive.
\end{abstract}

Key words: Anti-mycotoxin additives. Gut health. Immunology. Multi-contamination. Mycotoxin. Piglets.

\footnotetext{
${ }^{1}$ Discentes de Doutorado, Programa de Pós-Graduação em Ciência Animal, Escola de Ciências da Vida, Pontifícia Universidade Católica do Paraná, PUC, PR, Curitiba, PR, Brasil. E-mail: diegobmelo@hotmail.com; geovanebex@hotmail.com; chiara. domingues@hotmail.com

2 Discente de Mestrado, Programa de Pós-Graduação em Ciência Animal, Escola de Ciências da Vida, PUC, PR, Curitiba, PR, Brasil. E-mail: angela.fonseca@pucpr.edu.br

3 Profs., Programa de Pós-Graduação em Ciência Animal, Escola de Ciências da Vida, PUC, PR, Curitiba, PR, Brasil. E-mail: kelly.mazutti@pucpr.br; jair.engracia@pucpr.br; batista.leandro@pucpr.br

4 M.e, Pesquisador em Impextraco Latin America, Curitiba, PR, Brasil. E-mail: pedro@impextraco.com.br

5 Pesquisadora, Programa de Pós-Graduação em Ciência Animal, Escola de Ciências da Vida, PUC, PR, Curitiba, PR, Brasil. E-mail: carlazoobr@yahoo.com.br

Author for correspondence
} 


\section{Resumo}

Um experimento foi conduzido para avaliar os efeitos tóxicos da ingestão simultânea de baixos níveis de zearalenona, fumonisina e aflatoxinas em uma dieta para leitões recém desmamados e avaliar a eficácia de um aditivo antimicotoxinas. Durante 21 dias, os leitões foram expostos aos tratamentos controle ou multicontaminado com ou sem a inclusão do aditivo antimicotoxina. O desempenho dos animais foi avaliado após 21d. Foram coletadas amostras de sangue para análise bioquímica sérica e para quantificar os níveis de células imunes mononucleares circulantes. Foram avaliados os pesos e alterações histológicas dos órgãos e a expressão de COX-2 e TNF- $\alpha$ no fígado e no jejuno. Em geral, o tratamento com micotoxinas não teve efeito sobre as variáveis analisadas e não foram observadas alterações histopatológicas adversas nos órgãos. A concentração de proteína sérica total foi maior para os animais que receberam o tratamento com multimicotoxinas; no entanto, os níveis permaneceram dentro dos limites normais para leitões desmamados. A dieta multicontaminada com micotoxinas, na dose avaliada neste estudo, parece não afetar a saúde de leitões recém desmamados através dos parâmetros avaliados. A ausência de toxicidade associada ao tratamento com micotoxinas tornou impossível avaliar a eficácia do aditivo antimicotoxina.

Palavras-chave: Aditivo antimicotoxinas. Saúde intestinal. Imunologia. Multicontaminação. Leitões.

\section{Introduction}

Animal intake of mycotoxin-contaminated feed can, depending on time and level of exposure, result in acute or chronic toxicity. The outcome of mycotoxin toxicity can involve histological changes, as well as mutagenic, cytotoxic, teratogenic, carcinogenic, estrogenic, hematotoxic, and immunotoxic effects (CAST, 2003). Pigs are highly sensitive to mycotoxins and its exposure to these substances can decrease growth performance and feed intake, reduce immune resistance, and increase rates of infectious diseases and reproductive disorders (KANORA; MAES, 2009; BRYDEN, 2012). Further, production costs associated with the need for therapeutic drug administration can also increase.

Among mycotoxins producers, there is relevant concern about fungi species of Fusarium genera, that produce zearalenone (ZEA) and fumonisin (FB), and Aspergillus genera, producers of aflatoxin (AF) (BRYDEN, 2012). Based on worldwide surveys, Grenier and Applegate (2013) categorized experimental mycotoxin doses as realistic, occasional, or unrealistic according to the contamination levels found under most field conditions. However, animals are rarely exposed to a single type of mycotoxin and simultaneous multiple contamination has become a major health concern. This is because mycotoxin combinations could act synergistically to produce toxic effects (SPEIJERS; SPEIJERS, 2004; KLARIC et al., 2012).

Some feed additives have been evaluated as possible approaches to reduce the toxic effects of mycotoxins in animal production (JUAN-JUAN et al., 2010; YANG et al., 2012; FU et al., 2013). Clay minerals (JIANG et al., 2010a), enzymes (JARD et al., 2011), antioxidant vitamins (SORRENTI et al., 2013), natural biopolymers, and extracts (JUANJUAN et al., 2010; QUILES et al., 2015) have all been demonstrated to minimize the toxic effects of mycotoxins. However, reports on the use of antimycotoxin additives blended into contaminated diets are scarce (MACHADO JÚNIOR et al., 2014).

The toxic effects of mycotoxins in pigs, based on realistic doses that occur under most field conditions or on multi-contamination in the diet, are shown in only few studies (DILKIN et al., 2003; GRENIER et al., 2011; BRACARENSE et al., 2012). The extensive range of exposure levels and mycotoxin types associated with multi-contaminations increases the importance of such investigations as a means to protect the safety of food for human 
and animal consumption. Therefore, the aim of this study was to evaluate the combined effect of ZEA, $\mathrm{FB}$, and $\mathrm{AF}$, and the efficacy of an anti-mycotoxin additive blended in piglet's diet on growth performance, mononuclear immune cells, serum biochemical profile, organ weights and histological changes, and immunohistochemistry.

\section{Material and Methods}

\section{Animals and experimental design}

The experimental procedure was carried out in the animal facility at Pontifícia Universidade Católica do Paraná (PUCPR, Curitiba, Brazil) in accordance with guidelines of their Ethics Committee on the Use of Animals (CEUA-PUCPR, Protocol 0908). A total of 48 weanling piglets (24 castrated male and 24 female piglets), with an initial average body weight of $6.88 \pm 0.89 \mathrm{Kg}$, and at $21 \mathrm{~d}$ of age were assigned in a randomized block design to three treatments and eight replicates per treatment, during a short-term experimental period of $21 \mathrm{~d}$. The experimental unit comprised two animals (male/ male or female/female) receiving feed and water $a d$ libitum. However, to evaluate the treatment effects on weight of the reproductive tract, each female piglet was considered as an experimental unit; keeping 8 replicates/treatment.

\section{Experimental diets}

The formulated diets for this study were isocaloric and isonitrogenous (Table 1) to assure or exceed the nutrient required for piglets, based in Rostagno et al. (2011). High-performance liquid chromatography (HPLC) analysis characterized the treatments as the following contamination: T1 - basal diet, no detected mycotoxins, T2 - multicontaminated basal diet, 88.5 ppb ZEA, 3,994 ppb total FB $\left(2,577 \mathrm{ppb} \mathrm{FB}_{1}+1,417 \mathrm{ppb} \mathrm{FB}_{2}\right)$, and 107.5 ppb total AF (82.0 ppb $\mathrm{AFB}_{1}+1.5 \mathrm{ppb}^{\mathrm{AFB}} \mathrm{AF}_{2}+24.0$ ppb $\mathrm{AFG}_{1}$ ), and $\mathrm{T} 3$ - same mycotoxin levels of $\mathrm{T} 2$ plus an anti-mycotoxin additive. Only purified $\mathrm{AFB}_{1}$ was artificially incorporated into the $\mathrm{T} 2$ and $\mathrm{T} 3$. All the other mycotoxins were naturally present in raw material of the T2 and T3. The anti-mycotoxin additive incorporated into $\mathrm{T} 3$ is a mixture of natural biopolymer and herbal extracts, enzymes, vitamin $\mathrm{C}$, and hydrated sodium calcium aluminum silicates.

Table 1. Composition and calculated nutrients of the experimental basal $\operatorname{diet}^{1}$.

\begin{tabular}{lc}
\hline Item & Basal diet (\%) \\
\hline Feed Ingredients & \\
\hline Corn (8\% Crude Protein) & 51.10 \\
Soybean meal (46\% Crude Protein) & 25.00 \\
Vitamix $^{\circledR *}$ & 20.27 \\
Soybean oil & 1.70 \\
Limestone & 0.90 \\
Dicalcium phosphate & 0.30 \\
L-Lysine (78\%) & 0.38 \\
DL-Methionine (99\%) & 0.05 \\
L-Threonine (98\%) & 0.10 \\
Calcium Propionate & 0.20 \\
Total & 100.00
\end{tabular}


continuation

Nutrients

Calculated values

Crude Protein (\%)

18.53

Crude Fiber (\%)

2.33

Lactose (\%)

4.42

Calcium (\%)

0.82

Total phosphorus (\%)

0.63

Available phosphorus (\%)

0.41

Sodium (\%)

0.25

L-Lysine (\%)

1.54

DL-Methionine (\%)

0.40

Methionine + Cystine (\%)

0.69

Tryptophan (\%)

0.23

L-Threonine (\%)

0.83

Net energy (MJ)

13.96

${ }^{1}$ Composition of the basal diet for T1, T2, and T3. *Vitamix ${ }^{\circledR}$ supplied per Kg of the nucleus: $15.57 \%$ of crude protein; $7.59 \%$ of ether extract; $11.93 \%$ of mineral matter; $0.57 \%$ of crude fiber; $21.78 \%$ of lactose; $5.43 \%$ of milk protein; $1.64 \%$ of calcium; $1.49 \%$ of total phosphorus; $1.34 \%$ of available phosphorus; $1.22 \%$ of sodium; $1.39 \%$ of potassium, $2.0 \%$ of chloride; $1.69 \%$ of lysine; $0.70 \%$ of methionine; $0.96 \%$ of methionine + cystine; $0.29 \%$ of tryptophan; $1.03 \%$ of threonine; $0.80 \%$ of arginine; $1.3 \%$ of leucine; $0.72 \%$ of isoleucine; $0.38 \%$ of histidine; $0.75 \%$ of valine; $0.63 \%$ of phenylalanine; $13.96 \mathrm{MJ}$ of net energy; $50,000 \mathrm{UI}$ of vitamin A; 10,000 UI of vitamin D3; $160 \mathrm{mg}$ of vitamin E; $12 \mathrm{mg}$ of vitamin K3; $12 \mathrm{mg}$ of vitamin B1; $20 \mathrm{mg}$ of vitamin B2; $12 \mathrm{mg}$ of vitamin B6; $0.10 \mathrm{mg}$ of vitamin B12; $2.40 \mathrm{mg}$ of folic acid; $140 \mathrm{mg}$ of nicotinic acid; $88 \mathrm{mg}$ of pantothenic acid; $0.40 \mathrm{mg}$ of biotin; $1,248 \mathrm{mg}$ of colin; $800 \mathrm{mg}$ of Fe; $800 \mathrm{mg}$ of Cu; $220 \mathrm{mg}$ of $\mathrm{Mn} ; 3.20 \mathrm{mg}$ of Co; 5,000 mg of Zn; $7.20 \mathrm{mg}$ of I; $1.20 \mathrm{mg}$ of Se; $1.20 \mathrm{mg}$ of $\mathrm{Cr}$.

The diets with mycotoxin combinations present lower doses of ZEA and FB than recommended for EU guideline, while present doses of AF above of the regulatory levels (GUERRE, 2016).

\section{Animal growth performance}

The growth performance of each individual piglet was recorded on d21. Average daily gain (ADG), average daily feed intake (ADFI), and feed efficiency rate [Gain:Feed (G:F)] were determined.

\section{Flow cytometry and serum biochemistry}

Blood samples were taken via the jugular vein on d21 from the heaviest pig of each pen (a total of 24 animals, 8 replicates/treatment), independently of sex. Then, an 8-mL aliquot from each sample was aseptically collected in separate tubes containing the anticoagulant ethylenediaminetetraacetic acid
(EDTA, Becton Dickinson, New Jersey, USA) for analysis by flow cytometry (FERNANDES FILHO et al., 2013). Another 8-mL aliquot from each sample was collected in a tube without anticoagulant. This sample was taken for serum biochemistry analyses (JIANG et al., 2010a).

A volume of $180 \mu \mathrm{L}$ of the cell pellet (about $10^{6}$ cells) was used to that the specific monoclonal antibodies bind to the following respective recognized cell surface antigen: double positive $\mathrm{T}$ lymphocytes $\left(\mathrm{CD}^{+} / \mathrm{CD}^{+}\right)$, helper $\mathrm{T}$ lymphocytes $\left(\mathrm{CD}^{+} / \mathrm{CD} 8\right)$, cytotoxic $\mathrm{T}$ lymphocytes (CD4$\left.\mathrm{CD}^{+}\right)$, ratio between $\mathrm{CD} 4^{+} / \mathrm{CD} 8{ }^{-}: \mathrm{CD} 4^{-} / \mathrm{CD} 8^{+}$ (CD4:CD8), B lymphocytes (B cell subset), monocytes/granulocytes (CD172a), for $30 \mathrm{~min}$ at room temperature. The monoclonal antibodies were acquired from Southern Biotech (Birmingham, AL, USA) and data were analyzed with CellQuest Pro software (Becton Dickson, Franklin Lakes, NJ, USA). 
Blood aliquots fated to serum biochemistry analyses, collected as aforementioned (a total of 24 animals, 8 replicates/treatment), evaluated the liver function through the determination of aspartate aminotransferase(AST), gammaglutamyltransferase (GGT), and alkaline phosphatase (ALP) activities. Serum concentrations of albumin, creatinine, total protein, and urea were also determined. All serum parameters were measured by a semi-automatic biochemistry analyzer (Quick Lab II Drake, Belo Horizonte, MG - Brazil).

Organ weights, histology changes and immunohistochemical analysis

One day after the end of the experiment, 24 animals (12 female and 12 male piglets) with the highest body weight from each pen were slaughtered to register the relative organ weights (liver, kidney, and lung) $(\mathrm{n}=8)$. The other 12 female piglets were also slaughtered to evaluate the relative weight of reproductive tract (ovary, uterus, and vaginavestibule) (a total of 24 female piglets, $n=8$ ). The relative organ weights were calculated according to the final body weight of the piglets.

After the organ weight measurements, samples of the liver, kidney, lung, jejunum, ileum, uterus, and ovary were collected, fixed in $10 \%$ neutral buffered formalin solution, serially exposed to graded alcohol concentration, and embedded in paraffin. Sections of 4- $\mu \mathrm{m}$ thickness were obtained and stained with hematoxylin-eosin. Except for the intestine sections, the collected tissues were evaluated by light microscopy. The severity of damage was classified as no lesion, mild $(<25 \%$ to low extent), moderate (26-50\% to intermediate extent), or severe (>51\% to large extent).

Sections from the liver and jejunum were subjected to immunohistochemical analysis. The tissue microarray (TMA) technique was applied on the paraffin blocked tissue (BAURAKIADES et al., 2014) and sections were examined for expression of COX-2 (monoclonal antibody, clone SP21,
Spring Bioscience, Pleasanton, CA, USA) and TNF- $\alpha$ (monoclonal antibody, clone TA20, Santa Cruz Biotechnology, Heidelberg, Germany). The percentage of marked fields was observed with the aid of the Image Pro Plus 4.5 (Media Cybernetics, Silver Spring, MD, USA) and ZEN 2.0 Image software (Blue ed., Carl Zeiss Microscopy GmbH, 2011) for counting marked cells.

\section{Statistical analysis}

Data were analyzed using the Statgraphics ${ }^{\circledR}$ 4.1 software program. The data were subjected to ANOVA and Tukey's test to account for multiple comparisons. $P$ values $<0.05$ were considered statistically significant.

\section{Results and Discussion}

Mycotoxins can cause serious adverse effects on animal growth performance. In the present study, multi-mycotoxin treatment did not affect the feed consumption or weight gain (Table 2). A deleterious effect on piglet's growth performance was caused by the combination of $30,000 \mathrm{ppb}$ $\mathrm{FB}_{1}$ (high level) and $50 \mathrm{ppb} \mathrm{AFB}_{1}$ (DILKIN et al., 2003). At the present, the short co-exposure levels of ZEA, AF and FB required to affect piglet's growth performance remain unclear. However, our results enable state that in the period and dose tested, the multi-mycotoxin diet was not deleterious to the body weight gain, feed consumption or feed conversion.

The absence of toxicity associated with the multi-mycotoxin treatment rendered it impossible to evaluate the efficacy of an anti-mycotoxin additive. The mixed compounds of the anti-mycotoxin additive could reduce mycotoxin effects by acting differently on each mycotoxin present in the diet. The variety of mechanisms of action is an important feature for an efficient anti-mycotoxins additive due the occurrence of multi-mycotoxins in the feed and different molecular structure of each mycotoxin. 
Clay minerals and natural polymers are mycotoxin binders that reduce intestinal absorption of mycotoxins by acting as adsorbents or sequestering (JUAN-JUAN et al., 2010). However, the different molecular structure of FB (GRENIER et al., 2017), for example, and other mycotoxins became difficult its adsorption or sequestration. Thus, the presence of enzymes in anti-mycotoxins additives can degrade or transform no adsorbed mycotoxins in less toxic metabolites (DEVREESE et al., 2013). Other compounds such as herbal extracts and antioxidant agents could promoter intestinal protection like improved immune response, cell turnover and a role against the deleterious effect of the oxidative stress induced by mycotoxins (SORRENTI et al., 2013).

Table 2. Growth performance, relative organ weights ( $\%$ of body weight), immune and biochemical parameters of weanling piglets exposed to multi-mycotoxin diet with or without anti-mycotoxin additive.

\begin{tabular}{|c|c|c|c|c|c|}
\hline \multirow{2}{*}{ Item } & \multicolumn{3}{|c|}{ Treatment $^{1}$} & \multirow{2}{*}{ SEM $^{2}$} & \multirow{2}{*}{$P$ Value } \\
\hline & T1 & T2 & T3 & & \\
\hline \multicolumn{6}{|l|}{ Growth performance $^{3}$} \\
\hline $\mathrm{BW}, \mathrm{Kg}$ & 13.06 & 13.93 & 13.08 & 0.50 & 0.39 \\
\hline ADG, $g$ & 298 & 337 & 290 & 30 & 0.65 \\
\hline ADFI, $g$ & 489 & 516 & 448 & 36 & 0.44 \\
\hline Gain:Feed & 0.609 & 0.650 & 0.647 & 0.021 & 0.55 \\
\hline \multicolumn{6}{|l|}{ Organ weights, $\%$} \\
\hline Reproductive Tract & 0.72 & 0.80 & 0.68 & 0.03 & 0.06 \\
\hline Liver & 2.33 & 2.35 & 2.51 & 0.09 & 0.35 \\
\hline Kidney & 0.53 & 0.60 & 0.55 & 0.02 & 0.21 \\
\hline Lung & 2.01 & 2.70 & 2.04 & 0.13 & 0.71 \\
\hline \multicolumn{6}{|l|}{ Cell surface antigen ${ }^{4}, \%$} \\
\hline $\mathrm{CD}^{+} / \mathrm{CD}^{+}$ & 10.70 & 9.36 & 12.66 & 1.84 & 0.45 \\
\hline $\mathrm{CD}^{-} / \mathrm{CD}^{+}$ & 34.60 & 36.35 & 37.28 & 3.59 & 0.86 \\
\hline $\mathrm{CD}^{+} / \mathrm{CD} 8^{-}$ & 8.08 & 6.79 & 8.33 & 1.14 & 0.60 \\
\hline CD4:CD8 & 0.24 & 0.20 & 0.26 & 0.05 & 0.81 \\
\hline B cell subset & 2.87 & 4.02 & 2.67 & 0.52 & 0.18 \\
\hline CD172a & 0.74 & 0.75 & 0.60 & 0.10 & 0.56 \\
\hline \multicolumn{6}{|l|}{ Serum markers $^{5}$} \\
\hline $\mathrm{AST}^{3}, \mathrm{U} / \mathrm{L}$ & 52.37 & 48.75 & 44.12 & 5.84 & 0.61 \\
\hline $\mathrm{GGT}^{3}, \mathrm{U} / \mathrm{L}$ & 39.61 & 27.18 & 56.87 & 9.07 & 0.10 \\
\hline $\mathrm{ALP}^{3}, \mathrm{U} / \mathrm{L}$ & 92.81 & 119.19 & 92.81 & 10.96 & 0.18 \\
\hline Total Protein, g/dL & $4.37 \mathrm{~b}$ & $5.61 \mathrm{a}$ & $5.16 \mathrm{ab}$ & 0.31 & 0.04 \\
\hline Albumin, $\mathrm{g} / \mathrm{dL}$ & 2.10 & 2.58 & 2.22 & 0.14 & 0.07 \\
\hline Creatinine, $\mathrm{mg} / \mathrm{dL}$ & 1.03 & 1.05 & 1.08 & 0.04 & 0.70 \\
\hline Urea $\mathrm{N}, \mathrm{mg} / \mathrm{dL}$ & 17.91 & 17.56 & 20.86 & 3.47 & 0.76 \\
\hline
\end{tabular}

${ }^{\text {ab }}$ Different letters in the same line indicate statistical difference $(\mathrm{P}<0.05) .{ }^{1} \mathrm{~T} 1$ - basal diet (control), T2 - multi-contaminated basal diet with mycotoxins, and T3 - T2 plus an anti-mycotoxin additive $(\mathrm{n}=8) .{ }^{2} \mathrm{SEM}$ : The standard error of the mean. ${ }^{3} \mathrm{BW}$ : body weight, ADG: average daily gain, ADFI: average daily feed intake. ${ }^{4}$ Percentage of cells of peripheral blood: Double positive T lymphocytes $\left(\mathrm{CD}^{+} / \mathrm{CD}^{+}\right)$, Helper T lymphocytes $\left(\mathrm{CD}^{+} / \mathrm{CD} 8^{-}\right)$, Cytotoxic T lymphocytes (CD4 $\left./ \mathrm{CD}^{+}\right)$, Ratio between $\mathrm{CD} 4^{+} / \mathrm{CD}^{-}: \mathrm{CD}^{-} / \mathrm{CD}^{+}$ (CD4:CD8), B lymphocytes (B cell subset), Monocytes/Granulocytes (CD172a). ${ }^{5}$ AST: aspartate aminotransferase, GGT: gamma glutamyltransferase, ALP: alkaline phosphatase. 
Nevertheless, we can state that the antimycotoxin additive did not affect the feed intake or induce toxic response in weanling piglets. Also, it is important highlight that although the multicontaminated diets present lower doses of ZEA and $\mathrm{FB}$ than recommended for $\mathrm{EU}$ guideline for monocontamination, while present doses of $\mathrm{AF}$ above of the regulatory levels (GUERRE, 2016). Nevertheless, since in combinations, the mycotoxins were not toxic for young piglets.

Recurrent exposure to mycotoxins could also impair piglet's health by affecting intestinal inflammatory response (GRENIER; APPLEGATE, 2013) and tight junctions, increasing gut permeability and translocation of pathogenic agents
(BASSO et al., 2013). Hence the liver could be the following targeted organ of mycotoxins, since it is the major detoxifying organ, or yet to be target of translocated pathogenic agents. The combination of deoxynivalenol (DON) and $\mathrm{FB}_{1}$ pronouncedly reduced the expression of cytokines in spleen of piglets when compared to the group that received mono-mycotoxin (GRENIER et al., 2011). Thereof, we investigated COX-2 and TNF- $\alpha$ expression on liver and jejunum for being proinflammatory immediate-early genes induced at sites of inflammation (WANG; DUBOIS, 2010). However, multi-mycotoxin treatment did not affect COX-2 or TNF- $\alpha$ expression (Figure 1). Higher doses in shortterm exposure studies are most likely necessary to promote intestinal inflammation.

Figure 1. Immunohistochemical analysis (IHC) of COX-2- and TNF- $\alpha$ - expressing cells on liver and jejunum of weaning piglets exposed to T1 - basal diet (control), T2 - multi-mycotoxin diet, and T3 - T2 plus an anti-mycotoxin additive for 21 days of experiment $(n=8)$.
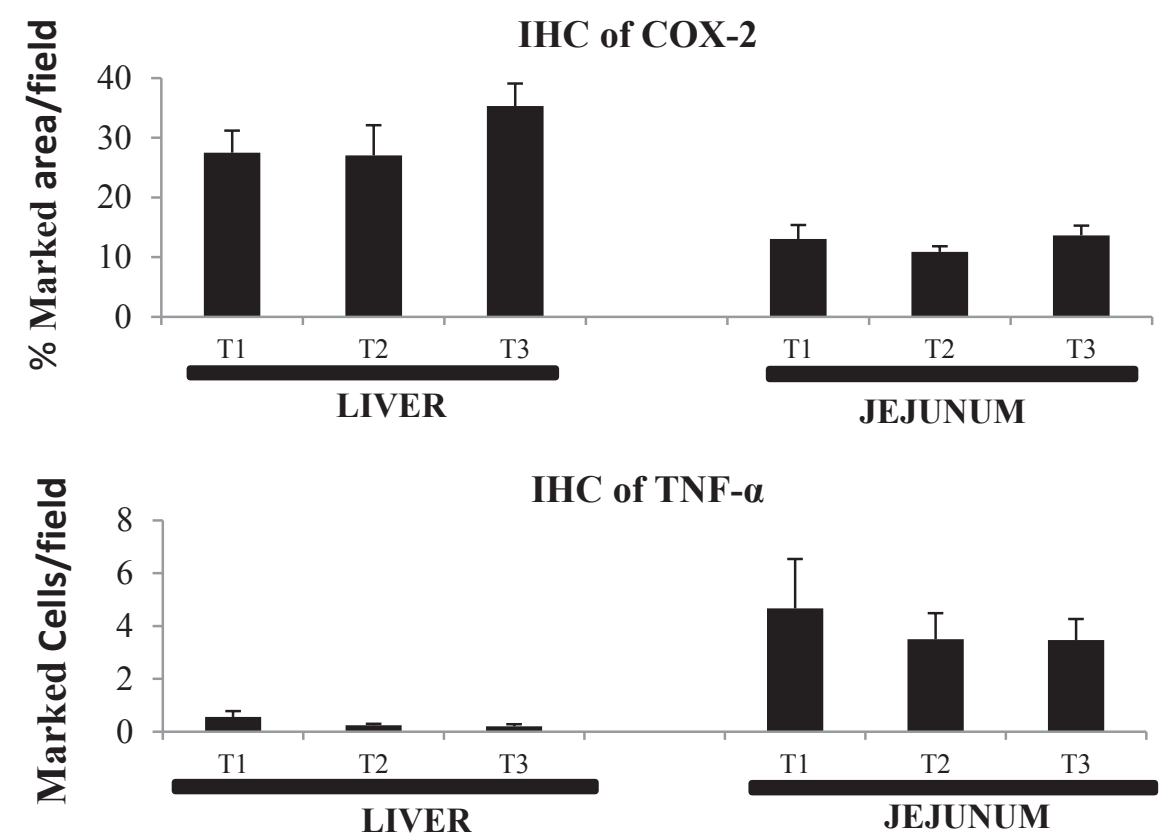

After intestinal absorption, mycotoxins are differentially distributed to tissue and organs (VOSS et al., 2001; ZOLLNER et al., 2002; FU et al., 2013). Consequently, toxic mono-contamination effects of ZEA, FB, and AF can increase relative organ weights and induce histopathological changes (CAST, 2003). However, there was no treatment effect on relative weight of liver, kidney, and lung 
(Table 2). In addition, the histopathological changes observed in these organs ranged from mild to moderate and no contrasting lesions were associated with multi-mycotoxin intake (Table 3).

Between the tested mycotoxins, only ZEA and its metabolites can bind to the estrogenic receptor present in the reproductive tract and cause an increase in estrogenic activity (GAJECKA et al., 2011, 2012; MUKHERJEE et al., 2014). One typical signal in female piglets is the enlargement of the reproductive tract (JIANG et al., 2010b, 2011; WANG et al., 2012). Alterations from the treatments on relative weights of reproductive tract (Table 2) was not detected. Information on the effect of low doses of ZEA in combination with other mycotoxins provided to female piglets, in short exposure, was not available until this study. However, different results could be attributed to differences in mycotoxins, dose levels, and exposure lengths.

Table 3. Histopathology analysis of piglets exposed to multi-contaminated treatments with mycotoxins.

\begin{tabular}{|c|c|c|c|}
\hline \multirow{2}{*}{ Treatment $^{1}$} & \multicolumn{3}{|c|}{ Organ analyzed } \\
\hline & Liver & Lung & Kidney \\
\hline $\mathrm{T} 1$ & Mild perilobular fibrosis & - & Mild glomerular degeneration \\
\hline $\mathrm{T} 1$ & Mild perilobular fibrosis & $\begin{array}{l}\text { Moderate congestion/ } \\
\text { mild interstitial edema/ } \\
\text { inflammatory infiltrate/ } \\
\text { cell proliferation }\end{array}$ & - \\
\hline $\mathrm{T} 1$ & Mild centrolobular congestion & - & - \\
\hline $\mathrm{T} 1$ & Moderate hydropic degeneration & - & - \\
\hline $\mathrm{T} 1$ & - & - & - \\
\hline $\mathrm{T} 1$ & - & $\begin{array}{l}\text { Mild mononuclear in- } \\
\text { filtrate }\end{array}$ & $\begin{array}{c}\text { Mild tubular degeneration and vacu- } \\
\text { olization }\end{array}$ \\
\hline $\mathrm{T} 1$ & - & Mild interstitial edema & $\begin{array}{l}\text { Mild medullar inflammatory infil- } \\
\text { trate }\end{array}$ \\
\hline $\mathrm{T} 1$ & $\begin{array}{l}\text { Mild hydropic degeneration/ } \\
\text { moderate inflammatory infiltrate } \\
\text { and hepatocytes degeneration }\end{array}$ & $\begin{array}{l}\text { Moderate interstitial } \\
\text { edema and cell prolif- } \\
\text { eration }\end{array}$ & $\begin{array}{l}\text { Moderate mononuclear infiltrate, tu- } \\
\text { bular degeneration, medullar inflam- } \\
\text { matory infiltrate and hemorrhage }\end{array}$ \\
\hline $\mathrm{T} 2$ & Mild centrolobular congestion & - & - \\
\hline $\mathrm{T} 2$ & $\begin{array}{l}\text { Moderate congestion/ mild vacu- } \\
\text { olization and perilobular fibrosis }\end{array}$ & - & - \\
\hline $\mathrm{T} 2$ & $\begin{array}{l}\text { Mild inflammatory infiltrate and } \\
\text { periportal fibrosis }\end{array}$ & Cell proliferation & Mild mononuclear infiltrate \\
\hline $\mathrm{T} 2$ & - & $\begin{array}{l}\text { Mild peribronchial hem- } \\
\text { orrhage }\end{array}$ & - \\
\hline $\mathrm{T} 2$ & - & $\begin{array}{l}\text { Mild congestion and } \\
\text { cell proliferation }\end{array}$ & Mild tubuloglomerular degeneration \\
\hline $\mathrm{T} 2$ & Moderate microvacuolization & $\begin{array}{l}\text { Mild congestion and } \\
\text { cell proliferation }\end{array}$ & - \\
\hline
\end{tabular}


continuation

\begin{tabular}{|c|c|c|c|}
\hline $\mathrm{T} 2$ & Mild mononuclear infiltrate & $\begin{array}{l}\text { Moderate interstitial } \\
\text { edema/ mild mono- } \\
\text { nuclear infiltrate }\end{array}$ & - \\
\hline $\mathrm{T} 2$ & Mild perivascular fibrosis & - & $\begin{array}{l}\text { Mild fibrosis area, mononuclear in- } \\
\text { filtrate and tubular degeneration }\end{array}$ \\
\hline $\mathrm{T} 3$ & $\begin{array}{l}\text { Moderate lobular degeneration/ } \\
\text { mild perilobular fibrosis }\end{array}$ & $\begin{array}{l}\text { Mild interstitial edema } \\
\text { and cell proliferation }\end{array}$ & - \\
\hline $\mathrm{T} 3$ & $\begin{array}{c}\text { Mild periportalhydropic degen- } \\
\text { eration }\end{array}$ & - & - \\
\hline $\mathrm{T} 3$ & - & - & - \\
\hline $\mathrm{T} 3$ & $\begin{array}{c}\text { Moderate to severe microvacu- } \\
\text { olization }\end{array}$ & Mild cell proliferation & - \\
\hline $\mathrm{T} 3$ & - & - & Severe glomerular degeneration \\
\hline $\mathrm{T} 3$ & - & - & Mild tubular degeneration \\
\hline $\mathrm{T} 3$ & Moderate edema & $\begin{array}{l}\text { Moderate cell prolifera- } \\
\text { tion }\end{array}$ & - \\
\hline $\mathrm{T} 3$ & - & $\begin{array}{l}\text { Mild congestion, hem- } \\
\text { orrhage and cell prolif- } \\
\text { eration }\end{array}$ & - \\
\hline
\end{tabular}

${ }^{1} \mathrm{~T} 1$ - basal diet (control); T2 - multi-contaminated basal diet with mycotoxins; and T3 - T2 plus an anti-mycotoxin additive (n=8). - No histopathological alteration.

Mycotoxins are reported to promote liver lesions, which can change liver enzymes and protein serum concentration in piglets (THIEU et al., 2008; JIANG et al., 2011). In our study, dietary exposure to ZEA, $\mathrm{FB}$, and $\mathrm{AF}$, at the tested levels, did not change the activity of the AST, GGT, or ALP enzymes (Table 2). Only the total protein concentration was increased $(\mathrm{P}<0.05)$ after $\mathrm{d} 21$ in piglets exposed to the multi-mycotoxin treatment (T2) compared to that in the control group (T1) (Table 2). However, the observed variation in total protein concentration found in this study was within the normal limit (4.0 to $5.8 \mathrm{~g} / \mathrm{dL}$ ) of pathogen-free 6 -week old piglets (COOPER et al., 2014). This suggests that there was no effect on liver function. In piglets, DON and FB in combination had less effect on biochemistry parameters than mono-contaminations and the authors, after to evaluate other studies testing the same mycotoxins, suggested an opposite effect of these two mycotoxins (GRENIER et al., 2011). At the present, it is unclear whether other co-contaminations in low doses could present pronounced effect on biochemical parameters in piglets. To better of our knowledgement, further experiments based on realistic doses (GRENIER; APPLEGATE, 2013), different mycotoxin combinations, or experimental periods of exposure in piglets should be considered; particularly as such studies will be most relevant to commercial livestock.

The mononuclear cells are predominant in chronic immune process and mediate cytokines release and humoral response. A decreased expression of IL- 6 mRNA in piglets exposed to 5,900 ppb FB has been associated with defective antigen presentation, impaired lymphocyte activation, and decreased IgG response (GRENIER et al., 2011). ZEA alone 
has been reported to reduce the humoral immunity response mediated by B cells (MARIN et al., 2011). Aflatoxin $\mathrm{B}_{1}$ has been reported to decrease cellmediated immunity (MEISSONNIER et al., 2008). The toxic effect of FB on the immune response has been shown to occur through inhibition of ceramide synthesis, as indicated by sphingoid base accumulation (MACHADO JÚNIOR et al., 2014). This mechanism can inhibit lymphocyte development and affect production of cytokines. Although the mechanism by which ZEA and AF affect the immune system remains unclear, the in vitro cytotoxic effect of $\alpha$-zearalenol can be enhanced by $\mathrm{FB}_{1}$ (LUONGO et al., 2006). However, after 21 $\mathrm{d}$, levels of circulating mononuclear cells, measured by flow cytometry, were not affected by the multimycotoxin treatment (Table 2). Taken together, these data could be of utility in determining legal limits for multi-contaminant levels of mycotoxins in swine feedstuffs.

\section{Conclusions}

During 21 days after weaning, a multicontaminated diet containing 88.5 ppb ZEA, 3,994 ppb FB, and 107.5 ppb AF did not exert negative effects on piglets' health, and the efficacy of the antimycotoxin additive was not posed due the absence of toxicity associated with the multi-mycotoxin treatment.

\section{Acknowledgments}

The authors thank the Impextraco Latin America ${ }^{\circledR}$ for financing and the Pontifícia Universidade Católica do Paraná (PUCPR) for supporting this study. Antonio Diego Brandão Melo also would like to thank for the support by a grant from CAPES, Brazil.

\section{Conflicts of interest}

The authors declare no conflict of interest.

\section{References}

BASSO, K.; GOMES, F.; BRACARENSE, A. P. L. Deoxynivalenol and fumonisin, alone or in combination, induce changes on intestinal junction complexes and in E-cadherin expression. Toxins, Basel, v. 5, n. 12, p. 23412352, 2013.

BAURAKIADES, E.; COSTA JÚNIOR, V. H.; RABONI, S. M.; ALMEIDA, V. R. T.; LARSEN, K. S. K.; KOHLER, J. N.; GOZZO, P. C.; KLASSEN, G.; MANICA, G. C. M.; NORONHA, L. The roles of ADAM33, ADAM28, IL-13 and IL-4 in the development of lung injuries in children with lethal non-pandemic acute infectious pneumonia. Journal of Clinical Virology, Amsterdam, v. 61, n. 4, p. 585-589, 2014.

BRACARENSE, A. P. L.; LUCIOLI, J.; GRENIER, B.; PACHECO, G. D.; MOLL, W. D.; SCHATZMAYR, G.; OSWALD, I. P. Chronic ingestion of deoxynivalenol and fumonisin, alone or in interaction, induces morphological and immunological changes in the intestine of piglets. British Journal of Nutrition, Southampton, v. 107, n. 12, p. 1776-1786, 2012.

BRYDEN, W. L. Mycotoxin contamination of the feed supply chain: implications for animal productivity and feed security. Animal Feed Science and Technology, Amsterdam, v. 173, n. 1-2, p. 134-158, 2012.

COUNCIL FOR AGRICULTURAL SCIENCE AND TECHNOLOG - CAST. Mycotoxins: risks in plant, animal, and human systems. Ames: Council for Agricultural Science and Technology (CAST), 2003. 199 p. (Task Force Report, No. 139).

COOPER, C. A.; MORAES, L. E.; MURRAY, J. D.; OWENS, S. D. Hematologic and biochemical reference intervals for specific pathogen free 6-week-old Hampshire-Yorkshire crossbred pigs. Journal of Animal Science and Biotechnology, London, v. 5, n. 1, p. 1-5, 2014.

DEVREESE, M.; BACKER, P.; CROUBELS, S. Different methods to counteract mycotoxin production and its impact on animal health. Vlaams Diergeneeskundig Tijdschrift, Ghent, v. 82, p. 181-189, 2013.

DILKIN, P.; ZORZETE, P.; MALLMANN, C. A.; GOMES, J. D. F.; UTYAMA, C. E.; OETTING, L. L.; CORRÊA, B. Toxicological effects of chronic low doses of aflatoxin $\mathrm{B}_{1}$ and fumonisin $\mathrm{B}_{1}$-containing Fusarium moniliforme culture material in weaned piglets. Food and Chemical Toxicology, Oxford, v. 41, n. 10, p. 13451353, 2003.

FERNANDES FILHO, T.; FÁVARO JÚNIOR, C.; INGBERMAN, M.; BEIRÃO, B. C. B.; INOUE, A.; GOMES, L.; CARON, L. P. Effect of spray Escherichia 
coli vaccine on the immunity of poultry. Avian Diseases, Ithaca, v. 57, n. 3, p. 671-676, 2013.

FU, J. C.; CHEN, Q.; DU, J.; SHI, B. M.; SHAN, A. S. Effectiveness of maifanite in reducing the detrimental effects of aflatoxin $\mathrm{B}_{1}$ on hematology, aflatoxin $\mathrm{B}_{1}$ residues, and antioxidant enzymes activities of weanling piglets. Livestock Science, Amsterdam, v. 157, n. 1, p. 218-224, 2013.

GAJECKA, M.; RYBARCZYK, L.; JAKIMIUK, E.; ZIELONKA, L.; OBREMSKI, K.; ZWIERZCHOWSKI, W.; GAJECKI, M. The effect of experimental long-term exposure to low-dose zearalenone on uterine histology in sexually immature gilts. Experimental and Toxicologic Pathology, Jena, v. 64, n. 6, p. 537-542, 2012.

GAJECKA,M.;RYBARCZYK,L.;ZWIERZCHOWSKI, W.; JAKIMIUK, E.; ZIELONKA, L.; OBREMSKI, K.; GAJECKI, M. The effect of experimental, long-term exposure to low-dose zearalenone mycotoxicosis on the histological condition of ovaries in sexually immature gilts. Theriogenology, Los Altos, v. 75, n. 6, p. 10851094, 2011.

GRENIER, B.; APPLEGATE, T. J. Modulation of intestinal functions following mycotoxin ingestion: meta-analysis of published experiments in animals. Toxins, Basel, v. 5, n. 2, p. 396-430, 2013.

GRENIER, B.; BRACARENSE, A. P. L.; LUCIOLI, J.; PACHECO, G. D.; COSSALTER, A. M.; MOLL, W. D.; SCHATZMAYR, G.; OSWALD, I. P. Individual and combined effects of subclinical doses of deoxynivalenol and fumonisin in piglets. Molecular Nutrition and Food Research, Weinheim, v. 55, n. 5, p. 761-771, 2011.

GRENIER, B.; SCHWARTZ-ZIMMERMANN, H. E.; GRUBER-DORNINGER, C.; DOHNAL, I.; ALESCHKO, M.; SHATZMAYR, G.; MOLL, W. D.; APPLEGATE, T. J. Enzymatic hydrolysis of fumonisins in the gastrointestinal tract of broiler chickens. Poultry Science, Oxford, v. 96, n. 12, p. 4342-4351, 2017.

GUERRE, P. Worldwide mycotoxins exposure in pig and poultry feed formulations. Toxins, Basel, v. 8, n. 350, p. 1-25, 2016.

JARD, G.; LIBOZ, T.; MATHIEU, F.; GUYONVARC'H, A.; LEBRIHI, A. Review of mycotoxin reduction in food and feed: from prevention in the field to detoxification by adsorption or transformation. Part A: chemistry, analysis, control, exposure and risk assessment. Food Additive and Contaminants, Abingdon, v. 28, n. 11, p. 1590-1609, 2011.

JIANG, S.; YANG, Z.; YANG, W.; GAO, J.; LIU, F.; CHEN, C.; CHI, F. Physiopathological effects of zearalenone in post-weaning female piglets with or without montmorillonite clay adsorbent. Livestock Science, Amsterdam, v. 131, n. 1, p. 130-136, 2010a.

JIANG, S.; YANG, Z.; YANG, W. R.; YAO, B. Q.; ZHAO, H.; LIU, F. X.; CHEN, C. C.; CHI, F. Effects of feeding purified zearalenone contaminated diets with or without clay enterosorbent on growth, nutrient availability, and genital organs in post-weaning female pigs. Asian Australasian Journal of Animal Science, Seoul, v. 23, n. 1, p. 74-81, 2010 b.

JIANG, S. Z.; YANG, Z. B.; YANG, W. R.; GAO, J.; LIU, F. X.; BROOMHEAD, J.; CHI, F. Effects of purified zearalenone on growth performance, organ size, serum metabolites, and oxidative stress in post weaning gilts. Journal of Animal Science, Champaign, v. 89, n. 10, p. 3008-3015, 2011.

JUAN-JUAN, L.; DE-CHENG, S.; XIAO-OU, S. Binding capacity for aflatoxin $\mathrm{B}_{1}$ by different adsorbents. Agricultural Sciences in China, Beijing, v. 9, n. 3, p. 449456, 2010.

KANORA, A.; MAES, D. The roles of mycotoxins in pig reproduction: a review. Veterinarni Medicina, Prague, v. 54, n. 12, p. 565-576, 2009.

KLARIC, M. S. Adverse effects of combined mycotoxins. Archives of Industrial Hygiene and Toxicology, Zagreb, v. 63, n. 4, p. 519-530, 2012.

LUONGO, D.; SEVERINO, L.; BERGAMO, P.; DE LUNA, R.; LUCISANO, A.; ROSSI, M. Interactive effects of fumonisin B1 and $\alpha$-zearalenol on proliferation and cytokine expression in Jurkat T cells. Toxicology in Vitro, Oxford, v. 20, n. 8, p. 1403-1410, 2006.

MACHADO JÚNIOR, P. C.; BEIRÃO, B. C. B.; FERNANDES FILHO, T.; INGBERMAN, M.; FÁVARO JÚNIOR, C.; CARON, L. F. Naturally contaminated feed with low levels of fumonisins with anti-mycotoxin additive and its impact in the immune cells and blood variables in broiler chicken. Journal of Toxicology and Environmental Health Sciences, Nairobi, v. 6, n. 10, p. 203-211, 2014.

MARIN, D. E.; IONELIA, T.; BURLACU, R.; MANDA, G.; MOTIU, M.; NEAGOE, I.; DRAGOMIR, C.; STANCU, M.; CALIN, L. Effects of zearalenone and its derivates on porcine immune response. Toxicology in Vitro, Oxford, v. 25, n. 8, p. 1981-1988, 2011.

MEISSONNIER, G. M.; PINTON, P.; LAFFITTE, J.; COSSALTER, A. M.; GONG, Y. Y.; WILD, C. P.; BERTIN, G.; GALTIER, P.; OSWALD, I. P. Immunotoxicity of aflatoxin B1: impairment of the cellmediated response to vaccine antigen and modulation of cytokine expression. Toxicology and Applied Pharmacology, New York, v. 231, n. 2, p. 142-149, 2008. 
MUKHERJEE, D.; ROYCE, S. G.; ALEXANDER, J. A.; BUCKLEY, B.; ISUKAPALLI, S. S.; BANDERA, E. V.; ZARBL, H.; GEORGOPOULOS, P. G. PhysiologicallyBased toxicokinetic modeling of zearalenone and its metabolites: application to the Jersey girl study. Plos One, San Francisco, v. 9, n. 12, p. 1-30, 2014.

QUILES, J. M.; MANYES, L.; LUCIANO, F.; MANES, J.; MECA, G. Influence of the antimicrobial compound allylisothiocyanate against the Aspergillus parasiticus growth and its aflatoxins production in pizza crust. Food and Chemical Toxicology, Oxford, v. 83, p. 222-228, 2015.

ROSTAGNO, H. S.; ALBINO, L. F. T.; DONZELE, J. L.; GOMES, P. C.; OLIVEIRA, R. F.; LOPES, D. C.; FERREIRA, A. S.; BARRETO, S. L. T.; EUCLIDES, R. F. Tabelas brasileiras para aves e suinos: composição de alimentos e exigências nutricionais. $3^{\text {th }}$ ed. Viçosa, MG: UFV, DZO, 2011. 252 p.

SORRENTI, V.; DI GIACOMO, C.; ACQUAVIVA, R.; BARBAGALLO, I.; BOGNANNO, M.; GALVANO, F. Toxicity of ochratoxin A and its modulation by antioxidants: a review. Toxins, Basel, v. 5, n. 10, p. 17421766, 2013.

SPEIJERS, G. J.A.; SPEIJERS, M. H. M. Combined toxic effects of mycotoxins. Toxicology Letters, Amsterdam, v. 153, n. 1, p. 91-98, 2004.

THIEU, N. Q.; OGLE, B.; PETTERSSON, H. Efficacy of bentonite clay in ameliorating aflatoxicosis in piglets fed aflatoxin-contaminated diets. Tropical Animal Health and Production, Edinburgh, v. 40, n. 8, p. 649-656, 2008.
VOSS, K. A.; RILEY, R. T.; NORRED, W. P.; BACON, C. W.; MEREDITH, F. I.; HOWARD, P. C.; PLATTNER, R. D.; COLLINS, T. F. X.; HANSEN, D. K.; PORTER, J. K. An overview of rodent toxicities: liver and kidney effects of fumonisins and Fusarium moniliforme. Environmental Health Perspectives, Durham, v. 109, p. 259-266, 2001. Supplement 2.

WANG, D.; DUBOIS, R. N. The role of COX-2 in intestinal inflammation and colorectal cancer. Oncogene, Basingstoke, v. 29, n. 6, p. 781-788, 2010.

WANG, J. P.; CHI, F.; KIM, I. H. Effects of montmorillonite clay on growth performance, nutrient digestibility, vulva size, faecal microflora, and oxidative stress in weaning gilts challenged with zearalenone. Animal Feed Science and Technology, Amsterdam, v. 178, n. 3-4, p. 158-166, 2012.

YANG, J.; BAI, F.; ZHANG, K.; LV, X.; BAI, S.; ZHAO, L.; PENG, X.; DING, X.; LI, Y.; ZHANG, J. Effects of feeding corn naturally contaminated with $\mathrm{AFB}_{1}$ and $\mathrm{AFB}_{2}$ on performance and aflatoxin residues in broilers. Czeck Journal of Animal Science, Prague, v. 57, p. 506515, 2012.

ZOLLNER, P.; JODLBAUER, J.; KLEINOVA, M.; KAHLBACHER, H.; KUHN, T.; HOCHSTEINER, W.; LINDNER, W. Concentration levels of zearalenone and its metabolites in urine, muscle tissue, and liver samples of pigs fed with mycotoxin-contaminated oats. Journal of Agricultural and Food Chemistry, Washington, v. 50, n. 9, p. 2494-2501, 2002. 